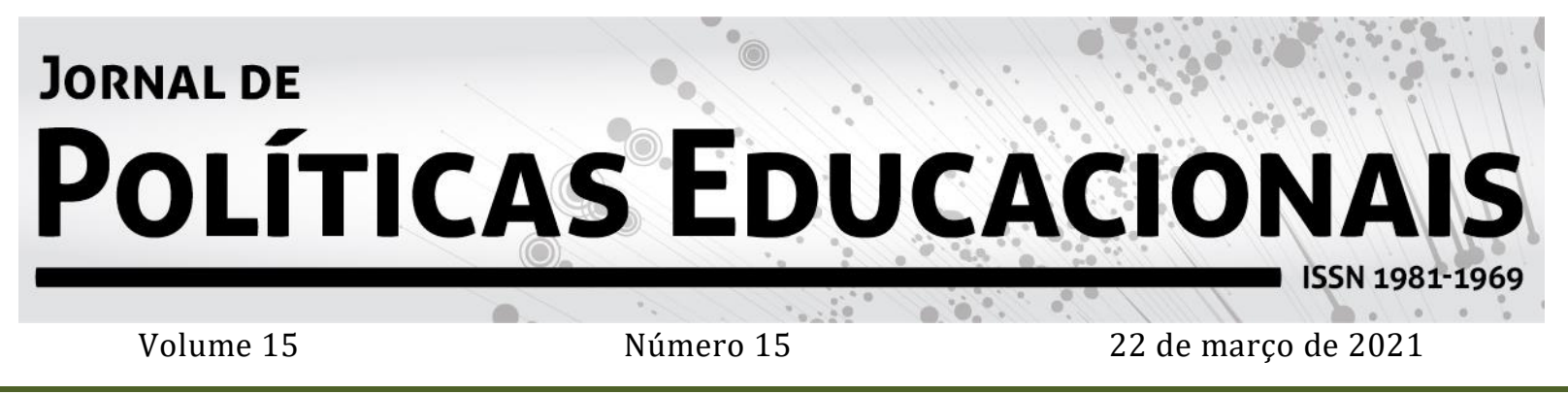

\title{
An Analysis of Antibullying Laws in Latin America and the Caribbean
}

\section{Uma Análise Comparativa das Leis Antibullying na América Latina e Caribe}

\section{Un Análisis Comparativo de las Leyes Antibullying en América Latina y Caribe}

\author{
Natalia Oliveira Woolley ${ }^{1}$ \\ James Macinko ${ }^{2}$ \\ Vanessa Rios-Salas ${ }^{3}$ \\ Jody Heymann ${ }^{4}$
}

Citação: WOOLLEY, N. O.; MACINKO, J.'; RÍOS-SALAS, V.; HEYMANN, J., An Analysis of Antibullying Laws in Latin America and the Caribbean. Jornal de Políticas Educacionais. V. 15, n. 15. Março de 2021.

\begin{abstract}
Young people in Latin America and the Caribbean (LAC) are disproportionately affected by interpersonal violence, including bullying. LAC governments have adopted anti-bullying legislation, but there has not been an in-depth analysis of these laws. This study provides a quantitative and descriptive analysis of laws in the region. Of the 33 countries in the region, 11 have enacted anti-bullying laws. Most countries do not have legislation. Among the identified laws, the scope of application and bullying behaviors were generally defined.
\end{abstract}

\footnotetext{
${ }^{1}$ Ph.D. Survey Manager/International Health. ICF. Los Angeles, California. USA. Orcid: http://orcid.org/00000002-3780-7006. E-mail: natalia.woolley@ucla.edu

${ }^{2}$ Ph.D. Professor/ Health Policy and Management and Community Health Sciences. UCLA. Los Angeles, California. USA. Orcid: http://orcid.org/0000-0001-8055-5441. E-mail: jmacinko@g.ucla.edu

${ }^{3}$ Ph.D. Researcher/Social Welfare. UCLA. Los Angeles, California. USA. Orcid: http://orcid.org/0000-00031299-7664. E-mail: fvaners@gmail.com

${ }^{4}$ Ph.D. M.D. Professor/International Health. WORLD Policy Analysis Center. Los Angeles, California. USA. Orcid: http://orcid.org/0000-0003-0008-4198. E-mail: jody.heymann@ph.ucla.edu
} 
WOOLLEY, N. O.; MACINKO, J.; RÍOS-SALAS, V.; HEYMANN, J., An Analysis of Antibullying Laws in Latin America and the Caribbean

Corrective measures lacked more detail, and few laws explicitly addressed mental health services. Future studies should focus on evaluating the implementation and effectiveness of these laws.

Keywords: Bullying, Cyberbullying, Youth, Evidence-Based Policy

\section{Resumo}

Os jovens da América Latina e do Caribe (LAC) são desproporcionalmente afetados pela violência interpessoal, incluindo o bullying. Os governos da ALC adotaram legislação anti-bullying, mas nenhuma análise aprofundada dessas leis foi realizada. Este estudo fornece uma análise quantitativa e descritiva das legislações da região. Dos 33 países na região, 11 promulgaram leis anti-bullying. A maioria dos países não possui legislação. Entre as leis identificadas, o escopo e os comportamentos de bullying foram amplamente definidos. As medidas corretivas careciam de mais detalhes e poucas leis abordavam explicitamente os serviços de saúde mental. Estudos futuros devem se concentrar na avaliação da implementação e eficácia dessas leis.

Palavras-chave: Bullying, Bullying Cibernético, Juventude, Política Baseada em Evidências

\section{Resumen}

Los jóvenes de América Latina y el Caribe (ALC) se ven afectados de manera desproporcionada por la violencia interpersonal, incluido el acoso. Los gobiernos de ALC han adoptado legislación contra el acoso, pero no se ha realizado un análisis en profundidad de estas leyes. Este estudio proporciona un análisis cuantitativo y descriptivo de las leyes de la región. De los 33 países en la región , 11 han promulgado leyes contra el acoso. La mayoría de los países no tienen legislación. Entre las leyes identificadas, se definieron en general el ámbito de aplicación y los comportamientos de intimidación. Las medidas correctivas carecían de más detalles y pocas leyes abordaban explícitamente los servicios de salud mental. Los estudios futuros deben enfocarse en evaluar la implementación y efectividad de estas leyes.

Palabras clave: Acoso Escolar, Ciberacoso, Adolescente, Política Informada por la Evidencia

\section{Introduction}

Over the past 20 years, low and middle-income countries have made great strides in increasing access to primary and secondary education, resulting in a growing proportion of children and adolescents now enrolled in school (THE WORLD BANK, 2014). Yet, in many places, the rise in school attendance has not been met with improvements in education quality (UNESCO, 2017). As a result, the global development community and local governments have sought to improve education quality by supporting teacher training, upgrading education facilities, and promoting a safer and more welcoming school environment (UNESCO, 2016).

However, despite efforts to make schools safer, thousands of youths suffer from violence at school or live in fear of being targeted (ELGAR ET AL., 2015; UNESCO, 2017). Bullying is the recurrent and unprovoked aggression between peers (OLWEUS, 1994), and it is one of the most widespread forms of school violence (ELGAR ET AL., 2015). Bullying can be direct aggression in the form of physical (e.g. punching and pushing) or verbal violence (e.g. calling names), or indirect aggression in the form of social exclusion (Wang, Iannotti, 
WOOLLEY, N. O.; MACINKO, J.; RÍOS-SALAS, V.; HEYMANN, J., An Analysis of Antibullying Laws in Latin America and the Caribbean

and Luk, 2012). Moreover, bullying can also take place online (e.g. cyberstalking) (ESPELAGE, RAO, AND CRAVEN, 2013)

Adolescence (10-19 years) is a period of great social, physical, and psychological change, and it is marked by the emergence of strong peer relationships (VINER ET AL., 2012). Therefore, peer violence, such as bullying, can negatively impact adolescents' development and well-being (KLJAKOVIC AND HUNT, 2016). For instance, bullying victims are at higher risk of suicide ideation, suicide attempts, and self-harm compared to those who are not bullied (JOHN ET AL., 2018; NIKOLAOU, 2017A; KIM AND LEVENTHAL, 2008). In addition, multi-country, cross-sectional studies have linked frequent bullying victimization to higher odds of having headaches and stomach aches (P. DUE et al., 2005), while both cross-sectional and longitudinal studies have found that bullying victims have higher rates of depression and anxiety (KALTIALA-HEINO ET AL., 2000; VAN DER WAL, DE WIT, AND HIRASING, 2003; GINI AND POZZOLI, 2009; COPELAND ET AL., 2013). Furthermore, the lifelong effects of bullying can extend beyond adolescents' health by also impacting their educational achievement. Adolescents who are bullied are less likely to feel a sense of belonging to the school community (GLEW ET AL., 2005), have significantly lower math and reading scores (DELPRATO, AKYEAMPONG, AND DUNNEB, 2017), and have a higher likelihood of dropping out of high school (CORNELL ET AL., 2013), compared to non-bullied students.

\section{Latin America}

The percentage of adolescents who report having been victims of bullying in Latin America and the Caribbean (LAC) ranges from $17 \%$ in Uruguay to $30 \%$ in the Dominican Republic (OECD, 2017). Trends have also varied, and while some countries such as Jamaica, Uruguay, and Trinidad and Tobago have recorded decreases in bullying (UNESCO, 2017), other countries, such as Brazil, have had an increase in self-reported bullying victimization during the same period (MALTA ET AL., 2014; AZEREDO ET AL., 2019).

Similar to their peers around the world, adolescents from LAC countries who experience bullying victimization are also more likely to report mental health problems (BOSA ET AL., 2018). Studies in the region also point that victimization is not equal across groups, and both students with disabilities (VEGA LÓPEZ ET al., 2013) and LQBTQ students tend to be at higher risk of bullying (KOSCIW, 2019). 
WOOLLEY, N. O.; MACINKO, J.; RÍOS-SALAS, V.; HEYMANN, J., An Analysis of Antibullying Laws in Latin America and the Caribbean

Bullying is one of the many types of violence youths in the LAC region must navigate daily. In addition, adolescents from LAC countries are exposed to some of the highest rates of violent crime (e.g. assault and homicide) in the world (UNODC, 2015), and are disproportionally affected by interpersonal violence (Global Burden of Disease Pediatrics et AL., 2016). The positive association between bullying aggression during adolescence and violent acts in adulthood (KIM ET AL., 2011), indicates that bullying prevention should be a priority in any comprehensive effort that LAC governments may undertake to decrease overall violence.

\section{Legal Interventions}

Emerging research in the United States has linked the enactment of antibullying laws to a reduction in student victimization (NIKOLAOU, 2017b). The development of antibullying laws conveys a clear message that bullying behaviors are unacceptable, raises awareness of the problem, and can help to engage broader society in addressing this problem (NATIONAL ACADEMIES OF SCIENCES AND MEDICINE, 2016; HALL, 2017). Antibullying laws can also promote a more sustained and multi-tiered approach in reducing bullying, which may include a combination of universal preventive efforts (e.g. bullying awareness campaigns) and more targeted interventions (e.g. mental health counseling for aggressors) (NATIONAL ACADEMIES OF SCIENCES AND MEDICINE, 2016).

Research on the content of these laws has been scarce and most studies on schoolbased antibullying laws have been based on state-level legislation in the United States (HALL, 2017). Nevertheless, emerging studies, along with guidelines established by international organizations such as UNICEF and UNESCO, support a few core legal components including specifications about the scope of application, definition of prohibited behaviors, protocols for when bullying occurs, and preventive measures (HATZENBUEHLER ET AL., 2015; UNESCO, 2017; PLAN INTERNATIONAL AND UNICEF, 2015; HALL, 2017; NATIONAL ACADEMIES OF SCIENCES AND MEDICINE, 2016).

Laws should be explicit as to where, what, and who these rules apply and protect. Antibullying laws should have a clear scope, stating, for example, the types of school (e.g. public, private), grades and locations (e.g. inside the school, outside the school) covered, and second, prohibited bullying behaviors should be explicitly defined (HATZENBUEHLER ET 
WOOLLEY, N. O.; MACINKO, J.; RÍOS-SALAS, V.; HEYMANN, J., An Analysis of Antibullying Laws in Latin America and the Caribbean

AL., 2015). Moreover, antibullying laws should also enumerate specific protections for groups (e.g. LGBTQ students or students with disabilities) who are at higher risk of being bullied (HALL, 2017).

Antibullying laws should also support schools in dealing with bullying occurrences. Corrective measures for aggressors, for instance, should prioritize restorative approaches, given their potential to improve school climate and to reduce bullying (UNESCO, 2017). The provision of mental health services to both victims and aggressors is also an important step in mitigating the consequences of this negative experience (UNESCO, 2017). Lastly, laws should establish reporting procedures to ensure readily available and confidential means of reporting not only for school staff but for anyone who has witnessed a bullying incident (UNESCO, 2017).

Strategies for bullying prevention (e.g. awareness campaigns and parent engagement) should also be considered as part of a comprehensive antibullying law (NATIONAL ACADEMIES OF SCIENCES AND MEDICINE, 2016). For example, teacher training on how to identify and address bullying is seen as a key aspect of implementing effective antibullying policies (UNESCO, 2017; STUART-CASSEL, BELL, AND SPRINGER, 2011). It is also important that schools develop their own antibullying policies so that preventive measures are tailored to each school context, and administrators feel empowered to act (HATZENBUEHLER ET AL., 2015). Furthermore, general legal components related to implementation, enforcement, evaluation, and monitoring are also important in the context of antibullying laws given their potential to increase the likelihood of adoption and impact of these laws (STUART-CASSEL, BELL, AND SPRINGER, 2011).

Many LAC countries have enacted school-based antibullying laws, policies, and programs in the past ten years to address the problem (DELPRATO, AKYEAMPONG, AND DUNNEB, 2017; TRUCCO, 2017; PLAN INTERNATIONAL AND UNICEF, 2015). Initial efforts, led mainly by international organizations such as UNICEF, have been made to compile these laws and to identify some of their overarching themes (PLAN INTERNATIONAL AND UNICEF, 2015; MORALES AND LÓPEZ, 2019; TRUCCO, 2017). However, these studies tended to employ a more superficial and descriptive approach, as opposed to a systematic assessment of specific legal components. The present study used evidence-based guidelines to compare LAC laws within nine specified domains and to identify gaps and opportunities for the legal 
WOOLLEY, N. O.; MACINKO, J.; RÍOS-SALAS, V.; HEYMANN, J., An Analysis of Antibullying Laws in Latin America and the Caribbean

landscape in the region. Results should also lay the groundwork for future legal antibullying interventions and impact evaluations across the region.

\section{Methods}

A comparative policy analysis was conducted to build a new database to assess important aspects of national antibullying laws for countries in Latin America and the Caribbean. This database was created at the WORLD Policy Analysis Center at the University of California Los Angeles and is available upon request.

\section{Antibullying Database}

The database included school-based, antibullying laws, and regulations enacted as stand-alone laws or amendments to existing legislation, up to December 31st, 2018. Laws were classified as school-based if they extended the scope to educational environments using at least one of the following terms: educational center, educational institution, educational unit, school, and school environment. Laws were classified as antibullying if they included terms such as violence among peers, school bullying, school harassment. Since there is no consensus on the Spanish equivalent for the word "bullying" (MARÍN-MARTÍNEZ AND REIDL MARTÍNEZ, 2013), all national, school-based laws containing the words acoso, hostigamiento and matonaje were included in the search strategy.

Sourcing of antibullying laws in the region was informed by systematic online searches, which entailed targeted Google searches using the native language, for all 33 countries in the region. Thorough reviews were carried out for the first three pages of Google results using the sourcing terms listed on the appendices section. Websites from the countries' national legislative bodies and national education ministries were also searched using the same key search terms. Table 1 contains the eleven laws that met the sourcing criteria established by the authors. 
WOOLLEY, N. O.; MACINKO, J.; RÍOS-SALAS, V.; HEYMANN, J., An Analysis of Antibullying Laws in Latin America and the Caribbean

Table 1

Overview of School-based, antibullying laws in Latin America and the Caribbean $(n=11)$

\begin{tabular}{|c|c|c|c|}
\hline Country & Name & Year & Type \\
\hline Argentina & $\begin{array}{l}\text { Law 26.892- For the promotion of coexistence } \\
\text { and the approach to social conflict in educational } \\
\text { institutions }\end{array}$ & 2013 & $\begin{array}{l}\text { National law and } \\
\text { resolutions } \\
(226 / 14 \text { and } \\
217 / 14)\end{array}$ \\
\hline Bolivia & $\begin{array}{l}\text { Law } 548 \text { - Amendment to the national law on } \\
\text { children and adolescents }\end{array}$ & 2014 & $\begin{array}{l}\text { Amendment and } \\
\text { regulation (2377) }\end{array}$ \\
\hline \multirow[t]{2}{*}{ Brazil } & $\begin{array}{l}\text { Law } 13.185 \text { - Program to combat systematic } \\
\text { bullying (bullying) }\end{array}$ & 2015 & National law \\
\hline & $\begin{array}{l}\text { Law 13.663-Amendment to the general } \\
\text { education law }\end{array}$ & 2018 & Amendment \\
\hline Chile & $\begin{array}{l}\text { Law 20.536- Amendment to the general } \\
\text { education law, "About school violence" }\end{array}$ & 2011 & Amendment \\
\hline Colombia & $\begin{array}{l}\text { Law } 1620 \text { - The national system of school } \\
\text { coexistence and training for the exercise of } \\
\text { human rights, education for sexuality and the } \\
\text { prevention and mitigation of school violence }\end{array}$ & 2013 & $\begin{array}{l}\text { National law and } \\
\text { regulation (1965) }\end{array}$ \\
\hline $\begin{array}{l}\text { Costa } \\
\text { Rica }\end{array}$ & $\begin{array}{l}\text { Law } 9404-\text { For the prevention and establishment } \\
\text { of corrective and formative measures against } \\
\text { to bullying or bullying }\end{array}$ & 2016 & National law \\
\hline $\begin{array}{l}\text { El } \\
\text { Salvador }\end{array}$ & $\begin{array}{l}\text { Decree 839- Legal reform of the law of integral } \\
\text { protection of children and adolescents }\end{array}$ & 2017 & National law \\
\hline Honduras & Law 96-2014- Against school bullying & 2015 & National law \\
\hline Panama & $\begin{array}{l}\text { Law } 7 \text { - That takes measures to prevent, prohibit } \\
\text { and punish discriminatory acts and dictates } \\
\text { other provisions }\end{array}$ & 2017 & National law \\
\hline Paraguay & $\begin{array}{l}\text { Law 4.633- Against school harassment in public } \\
\text { educational institutions, } \\
\text { private or private subsidized }\end{array}$ & 2012 & $\begin{array}{l}\text { National law and } \\
\text { resolution (5766) }\end{array}$ \\
\hline Peru & $\begin{array}{l}\text { Law } 29.719 \text { - That promotes the } \\
\text { coexistence without violence in educational } \\
\text { institutions }\end{array}$ & 2011 & $\begin{array}{l}\text { National law and } \\
\text { regulation (010- } \\
2012)\end{array}$ \\
\hline
\end{tabular}

${ }^{1}$ No laws were identified for 22 countries in the region

Coding was conducted by two native speakers who coded all legislative texts separately. A third reviewer, also fluent in one of the LAC countries' local languages, was consulted to resolve a few coding questions. 
WOOLLEY, N. O.; MACINKO, J.; RÍOS-SALAS, V.; HEYMANN, J., An Analysis of Antibullying Laws in Latin America and the Caribbean

\section{Analysis and Variables}

The present study provides descriptive data on legal components encompassing nine domains; 1) Scope; 2) Bullying Definition; 3) Protected Groups; 4) Reporting; 5) Corrective Measures; 6) Mental Health Support; 7) Preventive Measures; 8) Implementation and Enforcement; and 9) Monitoring and Evaluation. Variables of each domain were informed by U.S.-based studies of state antibullying laws and policies, and guidelines established by international organizations including UNICEF and UNESCO (PLAN INTERNATIONAL AND UNICEF, 2015; UNESCO, 2017; HALL, 2017; HATZENBUEHLER ET AL., 2015). The variable list was adapted to the content and format of LAC national laws to facilitate cross-national comparisons. For example, components of U.S. state laws outlining specific school district obligations (STUART-CASSEL, BELL, AND SPRINGER, 2011) were not included in the present variable list, since organizational structures in the educational system of LAC countries might differ from each other.

Most variables are dichotomous (yes/no). Consistent with previous content analysis of antibullying laws (STUART-CASSEL, BELL, AND SPRINGER, 2011), laws containing explicit language on the variable in question were coded as "yes". In addition to this, "other" was used to code additional themes that appeared consistently, and "unclear" was used to code the few instances where the legal excerpts were ambiguous.

\section{Results}

Out of the 33 countries in Latin America and the Caribbean, only eleven (33\%) have enacted national antibullying legislation. Among these countries, four enacted stand-alone antibullying laws (Brazil, Costa Rica, Honduras, and Paraguay), while the remaining countries amended existing legislation to include bullying prevention within a broader framework of school violence and/or discrimination prevention. Furthermore, all laws have been enacted within the past 10 years and since 2011 at least one law has been enacted every year.

\section{Scope, Definition, and Protected Groups}

Laws from all countries mentioned the type of schools under the scope of application, and all were applicable to both private and public schools [Table 2]. Eight out of 
WOOLLEY, N. O.; MACINKO, J.; RÍOS-SALAS, V.; HEYMANN, J., An Analysis of Antibullying Laws in Latin America and the Caribbean

Table 2

Scope \& Bullying Definition, By Country Law ( $n=11)$

\begin{tabular}{lllllllllllll}
\hline Domain & Variable & Ar & Bo & Br & Ch & Co & Cr & El & Ho & Pa & Pr & Pe \\
\hline Scope & Type of & $\checkmark$ & $\checkmark$ & $\checkmark$ & $\checkmark$ & $\checkmark$ & $\checkmark$ & $\checkmark$ & $\checkmark$ & $\checkmark$ & $\checkmark$ & $\checkmark$ \\
& School & $\checkmark$ & $\checkmark$ & $\checkmark$ & $\checkmark$ & $\checkmark$ & $\checkmark$ & & & $\checkmark$ & $\checkmark$ & $\checkmark$ \\
& Grade & $\checkmark$ & $*$ & $\checkmark$ & $\checkmark$ & $\checkmark$ & $\checkmark$ & - & - & $\checkmark$ & $\checkmark$ & $\checkmark$ \\
& Location & $\checkmark$ & - & - & $\checkmark$ & - & $\checkmark$ & $\checkmark$ & $\checkmark$ & - & $\checkmark$ & - \\
Bullying & Physical & - & $\checkmark$ & $\checkmark$ & - & $\checkmark$ & $\checkmark$ & $\checkmark$ & $\checkmark$ & $\checkmark$ & $\checkmark$ & $\checkmark$ \\
Definition & Verbal & - & $\checkmark$ & $\checkmark$ & - & $\checkmark$ & $\checkmark$ & $\checkmark$ & $\checkmark$ & $\checkmark$ & $\checkmark$ & $\checkmark$ \\
& Cyber & - & $\checkmark$ & $\checkmark$ & - & $\checkmark$ & $\checkmark$ & $\checkmark$ & $\checkmark$ & - & - & $\checkmark$ \\
& Other & $\checkmark$ & $\checkmark$ & $\checkmark$ & $\checkmark$ & $\checkmark$ & $\checkmark$ & $\checkmark$ & $\checkmark$ & $\checkmark$ & $\checkmark$ & $\checkmark$ \\
\hline
\end{tabular}

* Bolivia's law does not specify grade, but states that the law is applicable to all children in the national territory (Art. 4)

${ }^{1}$ Argentina- Although bullying is not explicitly defined in the law, Article 2 includes online violence as a possible medium in which school violence and harassment can occur. Art. 3 also establishes that schools should be free of physical and psychological violence, which are two forms of school bullying

${ }^{2}$ Chile- Art. $16 \mathrm{~B}$ provides a more general definition of bullying including that it can take place through technological means. However, it does not explicitly describe different forms of bullying. the eleven $(73 \%)$ also included information about the grades subjected to the scope. Within these eight countries, laws from Chile, Colombia, Costa Rica, and Paraguay were applicable starting with primary education, and up to secondary education. Laws from Argentina, Brazil, Paraguay, and Peru also included higher education institutions.

Most laws included a definition of physical and verbal bullying (82\%), which typically consisted of a description of physically aggressive behaviors (e.g. hitting and punching) for the first, and verbally aggressive behaviors (e.g. yelling and calling names) for the second. A description of bullying aggression through electronic means (i.e. cyberbullying) was also present in most legal texts (63\%).

\section{Reporting and Corrective Measures}

Laws from eight countries (73\%) contained information about reporting procedures in case of bullying [Table 3]. In contrast, only laws from three countries (27\%) included explicit protections from retaliation for reporting bullying incidents. Although not included in the table, it was noted that laws from Panama and Bolivia also contained information about the consequences of false bullying allegations. 
WOOLLEY, N. O.; MACINKO, J.; RÍOS-SALAS, V.; HEYMANN, J., An Analysis of Antibullying Laws in

Table 3

Reporting and Corrective Measures, By Country Law ( $n=11)$

\begin{tabular}{|c|c|c|c|c|c|c|c|c|c|c|c|c|}
\hline Domain & Variable & $\mathrm{Ar}$ & Bo & $\mathrm{Br}$ & Ch & Co & $\mathrm{Cr}$ & El & Ho & $\mathbf{P a}$ & Pr & $\mathbf{P e}$ \\
\hline \multirow[t]{2}{*}{ Reporting } & $\begin{array}{l}\text { Procedures } \\
\text { for reporting }\end{array}$ & $\checkmark$ & $\checkmark$ & - & $\checkmark$ & $\checkmark$ & $\checkmark$ & $\checkmark$ & - & $\checkmark$ & - & $\checkmark$ \\
\hline & $\begin{array}{l}\text { Protection } \\
\text { from } \\
\text { retaliation }\end{array}$ & - & - & - & - & $\checkmark$ & $\checkmark$ & - & - & $\checkmark$ & - & - \\
\hline \multirow[t]{5}{*}{$\begin{array}{l}\text { Corrective } \\
\text { Measures }\end{array}$} & $\begin{array}{l}\text { Proportional } \\
\text { to the offense }\end{array}$ & $\checkmark$ & - & - & $\checkmark$ & $\checkmark$ & $\checkmark$ & $*$ & $\checkmark$ & $\checkmark$ & $\checkmark$ & $\checkmark$ \\
\hline & $\begin{array}{l}\text { Age } \\
\text { appropriate }\end{array}$ & - & - & - & - & - & 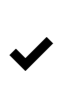 & - & $\checkmark$ & - & $\checkmark$ & $\checkmark$ \\
\hline & Respectful & - & - & - & - & - & $\checkmark$ & - & $\checkmark$ & - & $\checkmark$ & $\checkmark$ \\
\hline & $\begin{array}{l}\text { Educational/ } \\
\text { Rehabilitation } \\
\text { Peaceful }\end{array}$ & $\checkmark$ & - & - & $\checkmark$ & $\checkmark$ & $\checkmark$ & - & $\checkmark$ & - & - & $\checkmark$ \\
\hline & $\begin{array}{l}\text { Resolution of } \\
\text { Conflicts }\end{array}$ & $\checkmark$ & $\checkmark$ & - & - & $\checkmark$ & & - & - & - & - & $\checkmark$ \\
\hline
\end{tabular}

*El Salvador- Article 89 of this law states more generally that schools' disciplinary measures must be proportional and respectful but does not specify corrective measures in instances of bullying.

Notes:

Argentina- Art. 2 mentions respect for dignity in broader terms, but since it was not under the articles about corrective guidelines, it was not coded here.

Bolivia- Art. 153 establishes reporting of cases of bullying for reporting adults. No details are provided for students who report bullying.

Costa Rica- Art. 24 states that school staff who fails to protect students from retaliation will be sanctioned.

This is a less direct way to state that students are protected from retaliation, but it is a mean to safeguard

their protection, nevertheless.

Out of the five corrective measures assessed, the most common was that consequences should be proportional to the offense (82\%) and to provide an educational and rehabilitative opportunity for aggressors (55\%). In contrast, laws from only four countries explicitly stated that corrective measures should be tailored to students' age or development stage and be focused on the peaceful resolution of conflicts. Moreover, laws from three countries (27\%) explicitly stated that corrective measures should be respectful of aggressors' either physical or psychological integrity.

The Peruvian antibullying law "29719 que Promueve la Convivencia Sin Violencia en las Instituciones Educativas en Perú (2012)", was the only law to include all five corrective 
WOOLLEY, N. O.; MACINKO, J.; RÍOS-SALAS, V.; HEYMANN, J., An Analysis of Antibullying Laws in Latin America and the Caribbean

measure guidelines. The following excerpt from this law was used to code the corrective measures from Table 3:

Article 15. Criteria applicable to corrective measures

For the purposes of this Regulation, all corrective measures directed at students must be:

a) Clear and timely.

b) Repairing and training.

c) Respectful of the development stage of the students.

d) Pertinent to pedagogical development.

e) Respectful of the physical, psychological, and moral integrity of the students.

d) Proportional to the fault committed.

g) Established formally by the educational community and adapted to the conditions and needs of the students.

h) Respectful of the rights of children, girls, adolescents, and human rights

i) Related to the promotion of the Democratic Coexistence.

j) Consistent, fair and impartial, that do not depend on the state of mind of those who apply the corrective measures.

Article 16. - Objective of the corrective measures

The corrective measures must allow the students to reflect and learn from the lived experience, for which it is necessary to have the participation and commitment of the mothers, fathers and legal guardians, in order to contribute to their integral formation and Democratic coexistence in the educational institution.

\section{Mental Health Support and Preventive Measures}

Mental health services for victims were explicitly included in the laws from four countries (36\%) and laws from five countries (46\%) included these services for bullying aggressors as well [Table 4]. Laws from Argentina, Panama, and Paraguay contained more general language about support and counseling for students involved in bullying but did not explicitly state that these services included mental health counseling. These cases were coded as "other". 
Table 4

Mental Health Support and Preventive Measures, By Country Law (n=11)

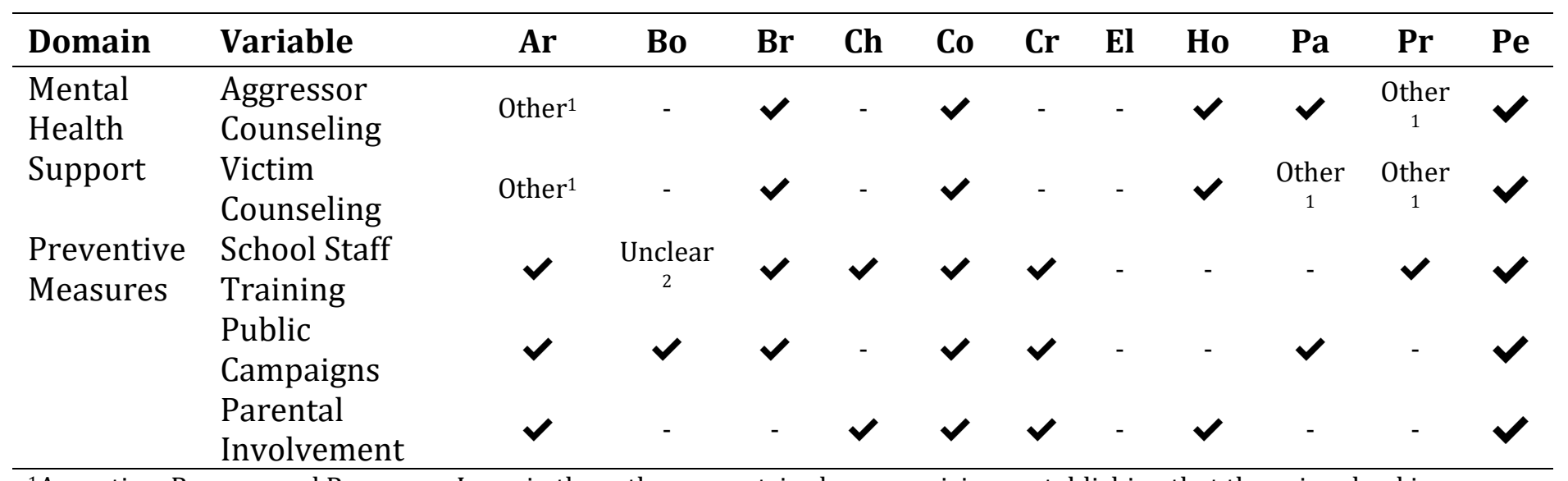

${ }^{1}$ Argentina, Panama and Paraguay- Laws in these three countries have provisions establishing that those involved in bullying (which for the purpose of this analysis is assumed to include both victims and aggressors) should have access to specialized support or professional assistance. However, the laws do not explicitly state whether these teams provide mental health counselling more specifically.

${ }^{2}$ Bolivia-Part III of art. 152 includes the organization and provision of training program aimed at bullying prevention, however it is not clear for whom the training is intended (e.g. students, school staff, etc.).

Note: Colombia- Art. 33 states that those "affected" by bullying will receive mental health attention. This was interpreted as both victims and aggressors for coding purposes. 
Except for El Salvador, laws from all countries explicitly included at least one strategy to prevent bullying. The most common prevention component was the promotion of peaceful coexistence measures (e.g. peaceful resolution of conflict) (82\%). School staff training and the creation of public awareness campaigns were included in $64 \%$ of the countries' laws. Parental involvement was explicitly included in $55 \%$ of the laws.

\section{Implementation and Enforcement, and Monitoring and Evaluation}

Laws from all countries included provisions for the development of schoolspecific policies or activities to address bullying [Table 5]. The following example from the Bolivian law “Código Niña, Niño y Adolescente (2014)” exemplifies the legal text used to code this variable:

Article 152. (PREVENTIVE MEASURES AND PROTECTION IN THE EDUCATIONAL SYSTEM).

I. In order to prevent, stop and eliminate violence, aggression and / or bullying in educational units and / or centers, the following collective actions are established that the educational community will adopt: d) Develop a peaceful and harmonious Coexistence Plan, according to the reality of each educational unit and / or center;

(...)

II. The Peaceful and Harmonious Coexistence Plan will be mandatory for each of the educational units and / or centers, and must be prepared by the higher authorities, in a participatory and plural open process, which mandatorily convene all the members of the educational community, within the framework of the Political Constitution of the State, international treaties and conventions on rights and guarantees of girls, boys and adolescents, according to the regulations.

All laws, except for the Salvadorian legislation, also addressed which entities or people were responsible for implementing at least one component of the law, 64\% explicitly outlined entities responsible for enforcement, and 55\% listed sanctions in cases of failure to comply. In addition, less than half included any mention of funding of at least one of the components of the law (33\%). 


\section{Table 5}

Implementation and Enforcement \& Monitoring and Evaluation, By Country Law ( $n=11)$

\begin{tabular}{|c|c|c|c|c|c|c|c|c|c|c|c|c|}
\hline Domain & Variable & $\mathbf{A r}$ & Bo & $\mathrm{Br}$ & Ch & Co & $\mathrm{Cr}$ & El & Ho & $\mathbf{P a}$ & Pr & $\mathbf{P e}$ \\
\hline \multirow{5}{*}{$\begin{array}{l}\text { Implementatio } \\
\mathrm{n} \\
\text { and } \\
\text { Enforcement }\end{array}$} & $\begin{array}{l}\text { School-specific } \\
\text { policies/activities }\end{array}$ & $\checkmark$ & $\checkmark$ & $\checkmark$ & $\checkmark$ & $\checkmark$ & $\checkmark$ & $\checkmark$ & $\checkmark$ & $\checkmark$ & $\checkmark$ & $\checkmark$ \\
\hline & $\begin{array}{l}\text { Implementation } \\
\text { responsibility }\end{array}$ & $\checkmark$ & $\checkmark$ & $\checkmark$ & $\checkmark$ & $\checkmark$ & $\checkmark$ & - & $\checkmark$ & $\checkmark$ & $\checkmark$ & $\checkmark$ \\
\hline & Funding & - & - & - & - & $\checkmark$ & - & - & $\checkmark$ & - & $\checkmark$ & $\checkmark$ \\
\hline & $\begin{array}{l}\text { Enforcement } \\
\text { responsibility }\end{array}$ & - & - & - & $\checkmark$ & $\checkmark$ & $\checkmark$ & - & $\checkmark$ & $\checkmark$ & $\checkmark$ & $\checkmark$ \\
\hline & $\begin{array}{l}\text { Non-compliance } \\
\text { sanctions }\end{array}$ & - & - & - & $\checkmark$ & $\checkmark$ & $\checkmark$ & - & $\checkmark$ & $\checkmark$ & - & $\checkmark$ \\
\hline \multirow[t]{2}{*}{$\begin{array}{l}\text { Monitoring } \\
\text { and Evaluation }\end{array}$} & $\begin{array}{l}\text { At least one } \\
\text { component of the } \\
\text { law evaluated } \\
\text { Systematic }\end{array}$ & - & $\checkmark$ & - & - & $\checkmark$ & $\checkmark$ & - & - & $\checkmark$ & - & $\checkmark$ \\
\hline & $\begin{array}{l}\text { bullying data } \\
\text { collection }\end{array}$ & - & $\checkmark$ & $\checkmark$ & - & $\checkmark$ & $\checkmark$ & - & $\checkmark$ & - & - & $\checkmark$ \\
\hline
\end{tabular}

Compared to the implementation and enforcement domain, laws from fewer countries included explicit information on monitoring and evaluation. Only laws in five countries (45\%) outlined a requirement to evaluate at least one component of the law, while six (55\%) established that bullying data had to be systematically collected. Some variation was also noted at the level in which bullying prevalence data was supposed to be collected and compiled ranging from the school to the national levels.

\section{Discussion}

Laws from eleven countries in the LAC region met the present study's inclusion criteria and provided protections to youths in some of the most populous countries in the region, such as Brazil and Colombia. Furthermore, since 2011 at least one new law has been enacted every year, indicating a rising awareness of the problem and growing demand for legislative solutions. Notably, Mexico, the second-most populous country in the region, had not enacted a national antibullying law at the time the database was created, and antibullying legislation in the country has been restricted to the state level (DIPUTADOS, 2013).

Despite a growing understanding of bullying and its potential impact on youth, most LAC countries (67\%) still lack national legislation. Moreover, different patterns emerged between Central America, South America, and the Caribbean. Most laws 
reviewed were enacted in South American countries, whereas no Caribbean country has adopted an antibullying law, according to this study's inclusion criteria. In contrast to Caribbean nations, antibullying legislation in Central and South America has been steadily increasing over the past ten years. In addition to bullying specific laws, recent analysis indicates that countries in Latin America are also pursuing laws and programs to more broadly support a peaceful school environment (MORALES AND LÓPEZ, 2019).

The present study contains both encouraging findings, and some gaps and challenges. On a promising note, all legislative texts reviewed included some aspect of three evidence-based components (Hatzenbuehler et al., 2015) (albeit with varying levels of detail); 1) a statement of scope; 2) a description of prohibited bullying behaviors; and 3 ) the requirement for schools to develop antibullying policies. These legal components are important because, as researchers have noted, they provide school administrators specificity and clarity to address bullying at the schools (HATZENBUEHLER ET AL., 2015).

The degree of legislative detail varied across domains. First, $46 \%$ of the laws did not explicitly determine whether incidents of student bullying outside the school were covered by the scope of the law. Establishing whether antibullying laws encompass aggressive behaviors outside the school is important especially because cyberbullying can take place anywhere.

The analysis also indicated that cyberbullying was explicitly included in fewer laws compared to physical bullying. Country-wide school closures in the region, due to the COVID-19 pandemic (UNESCO, 2020) have forced students to spend more time online to study and socialize, while also having less adult supervision as parents and caregivers need to meet work from home demands. Growth in internet access and social media use in the LAC region (ECLAC, 2016) will present new opportunities for online bullying and harassment. LAC governments should seriously consider cyberbullying as an intrinsic part of all bullying prevention activities. Besides, governments must pay close attention to how cyberbullying during the pandemic might further exacerbate the negative effects of prolonged social distancing and lack of in-person education on youths' mental health and development.

Unlike cyberbullying, physical bullying was generally defined across all laws, and the behaviors used to describe it were consistent across laws, possibly indicating a crossnational consensus around bullying at its most commonly understood form. Two countries, Brazil and Costa Rica also included sexual violence as a form of bullying. This Jornal de Políticas Educacionais. V. 15, n. 15. Março de 2021 
example suggests that although the definition of bullying may differ across countries, the variety of bullying forms present in the laws indicates that regional understanding of the topic goes beyond simple physical aggression and acknowledges the complexity of behaviors that can be categorized as bullying.

Another common component across laws called for schools to develop antibullying policies. The development of such policies allows the tailoring of antibullying prevention to each school context (STUART-CASSEL, BELL, AND SPRINGER, 2011). The process of developing these policies can also raise awareness about the problem among school staff and the larger school community, and possibly facilitate the implementation process.

It is also encouraging to note that many laws had a multicomponent approach, where both universal preventive approaches (e.g. schoolwide awareness campaigns) and interventions reaching select students (e.g. mental health counseling) were integrated as part of a multi-tiered preventive framework often recommended by experts (National Academies of Sciences and Medicine, 2016). Furthermore, preventive approaches often went beyond public antibullying campaigns, to include school staff training and parental participation in the prevention toolkit.

Four important gaps stood out. First, few laws included a list of protected groups. Second, a limited number of laws protected students from retaliation for reporting bullying, with two laws adding possible sanctions for false reporting. Third corrective measures, when present, often lacked detail about specific services and protections for both victims and aggressors. Fourth, provisions that can support the implementation of the laws, such as sanctions for noncompliance and evaluation processes, were absent from many laws.

Only laws from three countries (27\%) explicitly included a list of protected groups. These figures are in line with U.S. state laws, where a 2011 review concluded that only $37 \%$ of states had laws that enumerate higher vulnerability groups (STUARTCASSEL, BELL, AND SPRINGER, 2011). Nevertheless, the addition of protected groups is a growing trend in the U.S. (WINBURN, WINBURN, AND NIEMEYER, 2014) due to emerging research linking explicit protections to lower rates of bullying victimization (HALL, 2017). However, the adoption of explicit protections may be hindered by a lack of political consensus as the discussion to add protected groups to existing antibullying laws has been fractured along party lines in the U.S. (WINBURN, WINBURN, AND NIEMEYER, Jornal de Políticas Educacionais. V. 15, n. 15. Março de 2021 
2014). This impasse may also be a problem in some LAC countries such as Brazil, where the federal government has shown increasing animosity towards minority groups such as the LGBTQ community, and Belize and Guyana, where LBGTQ rights are still limited (CORRALES, 2015).

Explicit mention of bullying reporting procedures was included in the laws from eight countries (73\%). Yet, most laws offered few specifics regarding the reporting processes. Moreover, some laws only mention reporting means (i.e. by phone or inperson), while others only address reporting from certain individuals (e.g. parents). This finding stands in contrast to expert recommendations that call for convenient and confidential means of reporting not only for school staff but for anyone who has witnessed a bullying incident (UNESCO, 2017). It was also observed that laws from both Panama and Bolivia, also contained information about possible consequences against false allegations of bullying. These provisions could place an unfair onus on victims and make them less likely to report bullying incidents.

A wide variation in the level of detail was noted in the corrective measures domain, a finding in line with previous reviews of U.S. antibullying laws (STUART-CASSEL, BELL, AND SPRINGER, 2011). Most laws included at least one measure assessed, and the Peruvian law included all five. One potential reason is that these disciplinary measures are more likely to be part of individual schools' policies than delineated by national legislation. Nevertheless, future legislation on the topic needs to explicitly state safeguards for aggressors to ensure that disciplinary measures are restorative and help to re-integrate those students into the academic community.

Most laws also did not explicitly include access to psychological counseling for either victims or aggressors. These services are key to support students' coping skills and to mitigate the potential long-term effects of bullying experiences (STUART-CASSEL, BELL, AND SPRINGER, 2011). In the context of LAC countries, the provision of these services may be particularly difficult for students in public schools, even in countries where this safeguard exists (AZEREDO ET AL., 2019). Public schools in the region are often under-resourced and tasked with educating youths with fewer means to access psychological support privately (OECD, 2017). Therefore, ensuring that students across all types of schools and socioeconomic backgrounds have access to the appropriate support services can help to address not only bullying but also to alleviate the social and health inequalities in the region. 
This study also noted an absence of explicit sanctions for noncompliance and legal provisions related to monitoring and evaluation. A lack of sanctions for noncompliance can undermine antibullying laws as there are few consequences to schools that fail to protect youths. Monitoring and evaluation provisions are also key to iterating and revising antibullying laws in order to make them more effective and to measure their impact.

It is important to mention two limitations of the present study. First, the database does not include norms, decrees, or programs issued by national governments or by administrative agencies such as ministries of education. State, district, and municipal legislation were not examined at this time either. In addition, this study did not assess the implementation of existing laws. Despite these limitations, documentation and examination of national-level legislation offer an important framework moving forward. Based on the information compiled, future studies can assess whether the enactment of antibullying laws has had a positive impact on the prevalence of school bullying. Furthermore, these studies can investigate, more specifically, which legal components are more meaningful in reducing bullying victimization.

The present study also highlighted some key opportunities moving forward. Lawmakers in the region should consider including explicit protections for vulnerable groups, such as LGBTQ students and those with disabilities, ensuring accessible and confidential reporting of bullying incidents and providing more details on corrective measure guidelines. Antibullying laws should also have provisions detailing sanctions for noncompliance and evaluation mechanisms to assess their effectiveness. These changes could facilitate the adoption of these laws and to ultimately create a positive impact on students' safety and well-being.

\section{References}

AZEREDO, Catarina Machado, et all. 'Progress and setbacks in socioeconomic inequalities in adolescent health-related behaviours in Brazil: results from three crosssectional surveys 2009-2015', BMJ Open, 9: e025338, 2019.

BOSA, M. R., M. C. C. BOHÓRQUEZ, C. F. P. OLARTE, and J. K. S. Malaver. 'Diferencias por sexo en la intimidación escolar y la resiliencia en adolescentes', Psicologia Escolar e Educacional, 22: 519-26, 2018.

COPELAND, W. E., et all. 'Adult psychiatric outcomes of bullying and being bullied by peers in childhood and adolescence', JAMA Psychiatry, 70: 419-26, 2013. 
CORNELL, Dewey, et all. 'Perceived prevalence of teasing and bullying predicts high school dropout rates', Journal of Educational Psychology, 105: 138, 2013.

CORRALES, J. 'The Politics of LGBT Rights in Latin America and the Caribbean: Research Agendas ', European Review of Latin American and Caribbean Studies 100: 53-62, 2015.

DELPRATO, M. 'The impact of bullying on students' learning in Latin America: A matching approach for 15 countries', International Journal of Educational Development, 52: Pages 37-57, 2017.

DIPUTADOS, Cámara de. "Marco jurídico del acoso escolar (Bullying)." In. ECLAC. 2016. "La nueva revolución digital: de la Internet del consumo a la Internet de la producción." In. Santiago, 2013.

ELGAR, F. J., B. Et all. 'Structural determinants of youth bullying and fighting in 79 countries', J Adolesc Health, 57: 643-50, 2013.

ESPELAGE, D.L., M. A.; CRAVEN, R.G. Principles of Cyberbullying Research: Definitions, Measures, and Methodology (Routledge), 2013.

GINI, G.; POZZOLI, T. 'Association between bullying and psychosomatic problems: a meta-analysis', Pediatrics, 123: 1059-65, 2009.

GLEW, Gwen M., et all. Bullying, Psychosocial Adjustment, and Academic Performance in Elementary School', Archives of Pediatrics \& Adolescent Medicine, 159: 1026-31, 2005.

Global Burden of Disease Pediatrics. 'Global and National Burden of Diseases and Injuries Among Children and Adolescents Between 1990 and 2013: Findings From the Global Burden of Disease 2013 Study', JAMA Pediatr, 170: 267-87, 2016.

HALL, W. 'The Effectiveness of Policy Interventions for School Bullying: A Systematic Review', J Soc Social Work Res, 8: 45-69, 2017.

HATZENBUEHLER, M. L., L. et all. 'Associations Between Antibullying Policies and Bullying in 25 States', JAMA Pediatr, 169: e152411, 2015.

JOHN, A., A. C. et all. 'Self-Harm, Suicidal Behaviours, and Cyberbullying in Children and Young People: Systematic Review', J Med Internet Res, 20: e129, 2018.

KALTIALA-HEINO, R., M. et all. 'Bullying at school--an indicator of adolescents at risk for mental disorders', J Adolesc, 23: 661-74, 2000.

KIM, M. J., R. F. et all. 'Bullying at elementary school and problem behaviour in young adulthood: a study of bullying, violence and substance use from age 11 to age 21', Crim Behav Ment Health, 21: 136-44, 2011.

KIM, Y. S., and LEVENTHAL, B. 'Bullying and suicide. A review', Int J Adolesc Med Health, 20: 133-54, 2008. 
KLJAKOVIC, M., and HUNT, C. 'A meta-analysis of predictors of bullying and victimisation in adolescence', J Adolesc, 49: 134-45, 2016.

KOSCIW, J. G.; ZONGRONE, A. D. "A Global School Climate Crisis: Insights on Lesbian, Gay, Bisexual, Transgender \& Queer Students in Latin America." In: edited by GLSEN. New York, 2019.

MALTA, D. C., D. L. et all. 'Bullying in Brazilian school children: analysis of the National Adolescent School-based Health Survey (PeNSE 2012)', Rev Bras Epidemiol, 17 Suppl 1: 92-105, 2014.

MARÍN-MARTÍNEZ, A., REIDL MARTÍNEZ, L. M. 'Validación psicométrica del cuestionario "Así nos llevamos en la escuela" para evaluar el hostigamiento escolar (bullying) en primarias', Revista mexicana de investigación educativa, 18: 11-36, 2013.

MORALES, Macarena; LÓPEZ, Verónica. 'Convivencia escolar policies in Latin America: Four perspectives for comprehension and action', 2019, 27, 2019.

NATIONAL ACADEMIES OF SCIENCES. Engineering, and Medicine. Preventing Bullying Through Science, Policy, and Practice (The National Academies Press: Washington, DC). Nikolaou, D. 2017a. 'Does cyberbullying impact youth suicidal behaviors?', J Health Econ, 56: 30-46, 2016.

NIKOLAOU, Dimitrios. 'Do anti-bullying policies deter in-school bullying victimization?', International Review of Law and Economics, 50: 1-6, 2017b.

OECD. "PISA 2015 Results (Volume III): Students'Well-Being." In. Paris: OECD Publishing, 2017.

OLWEUS, D. 'Bullying at school. Basic facts and an effective intervention programme', Promot Educ, 1: 27-31, 48, 1994.

Plan International and UNICEF. 'Toolkit and Analysis of Legislation and Public Policies To Protect Children and Adolescents from all Forms of Violence in Schools', 2015. Accessed 04/03/2019. http://www.ungei.org/Toolkit and Analysis of Legislation and Public Policies To Prot ect Children and Adolescents from all Forms of Violence in Schools ENG(1).pdf.

STUART-CASSEL, V., A. et all. "Analysis of State Bullying Laws and Policies." In.: U.S. Department of Education, 2011.

THE WORLD BANK. 'School enrollment, primary (\% net)', Accessed 03/23/2018. Trucco, Daniela; Inostroza, Pamela. 2017. "Las violencias en el espacio escolar." In, edited by United Nations, 2014.

UNESCO. "Incheon Declaration and SDG4 - Education 2030 Framework for Action. In. - - 2017. "School Violence and Bullying: Global Status Report." In. Paris: United Nations Educational, Scientific and Cultural Organization, 2016. 
WOOLLEY, N. O.; MACINKO, J.'; RÍOS-SALAS, V.; HEYMANN, J., An Analysis of Antibullying Laws in Latin America and the Caribbean

.'COVID-19 Impact of Education', 2020. Accessed 06/12/2020.

https://en.unesco.org/covid19/educationresponse.

UNODC. 'UNODC Statistics; Crime and Criminal Justice', 2015. Accessed 1/24/2018.

https://data.unodc.org.

VAN DER WAL, M. F., C. A. et all. 'Psychosocial health among young victims and offenders of direct and indirect bullying', Pediatrics, 111: 1312-7, 2003.

VEGA LÓPEZ, María Guadalupe, et all. 'Bullying in the metropolitan area of Guadalajara, Mexico: prevalence and associated factors', Salud Colectiva, 9: 183-94, 2013.

VINER, R. M., E. M., et all. 'Adolescence and the social determinants of health', Lancet, 379: 1641-52, 2012.

WANG, J., R. J. et all. 'Patterns of adolescent bullying behaviors: physical, verbal, exclusion, rumor, and cyber', J Sch Psychol, 50: 521-34, 2012.

WINBURN, J., A. et all. 'Media coverage and issue visibility: State legislative responses to school bullying', Social Science Journal, 51: 514-22, 2014. 


\title{
JORNAL DE \\ Políticas EducacionaIS \\ ISSN 1981-1969 \\ Volume 15 \\ Número 15 \\ 22 de março de 2021
}

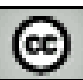

SORERIGHIS RESERNED O Copyright é retido pelo/a autor/a (ou primeiro co-autor) que outorga o direito da primeira publicação ao Jornal de Políticas Educacionais. Mais informação da licença de Creative Commons encontram-se em http://creativecommons.org/licenses/by-nc-nd/2.5. Qualquer outro uso deve ser aprovado em conjunto pelo/s autor/es e pelo periódico.

JoRnal DE PolíTiCAS EdUCACIONAIS é uma publicação do Núcleo de Políticas Educacionais do Setor de Educação da Universidade Federal do Paraná - NuPE/UFPR, em consórcio com a Linha de Pesquisa em Políticas Educacionais do Programa de Pós-Graduação em Educação - PPGE/UFPR, que aceita colaboração, reservando-se o direito de publicar ou não o material espontaneamente enviado à redação. As colaborações devem ser enviadas ao NuPE/UFPR, conforme orientações contidas nas páginas do periódico na internet: http://revistas.ufpr.br/ipe.

\section{INDEXAÇÃO:}

BASE DE DADOS
Sumário.Org
Google Scholar
BASE
Dimensions
Miar

DIRETÓRIOS
Diadorim
DOAJ
Erih Plus
Latindex
EZB
ROAD
Journal 4-free

\author{
ÍNDICES \\ Index Copernicus \\ Cite Factor \\ PORTAIS \\ LiVre \\ Capes \\ Science Open \\ World Wide Science
}

(Periódico integralmente disponível apenas em via eletrônica)

Jornal de Políticas Educacionais / Núcleo de Políticas Educacionais da Universidade Federal do Paraná NuPE/UFPR - v.1, n. 1 (1ํㅗ semestre de 2007) - Curitiba: NuPE/UFPR.

Volume 15, número 15 - Março de 2021

ISSN 1981-1969

1. Educação - Periódicos. 2. Política Educacional - Periódicos. I. NuPE/UFPR 
Comitê Editorial:

Elisângela Scaff (UFPR)

Daniela de Oliveira Pires (UFPR)

Conselho Editorial:

Andréa Barbosa Gouveia (UFPR - Brasil), Angela Maria Martins (FCC, Brasil), Antonia Almeida Silva (UEFS, Brasil), Cesar Tello (Universidad Nacional Tres Febrero, Argentina), Cristiane Machado (Unicamp- Brasil), Elton Luiz Nardi (UNOESC, Brasil), Fernanda Saforcada (Universidad de Buenos Aires - UBA - Argentina), Gladys Beatriz Barreyro (USP - Brasil), Gilda Cardoso Araújo (UFES - Brasil), Gustavo Enrique Fischman (Arizona State University - USA), Janete Maria Lins de Azevedo (UFPE, Brasil), Jefferson Mainardes (UEPG Brasil), João Ferreira de Oliveira (UFG - Brasil), Jorge Manuel Gorostiaga (UNSAM - Argentina), Juca Gil (UFRGS - Brasil), Luciana Rosa Marques (UFPE, Brasil), Luiz Souza Júnior (UFPB - Brasil), Marcia Aparecida Jacomini (Unifesp-Brasil), Maria Dilnéia Espíndola Fernandes (UFMS, Brasil), Ney Cristina Monteiro de Oliveira (UFPA - Brasil), Nicolás Bentancur, (Universidad de la República de Uruguay), Nora Krawczyk (Unicamp- Brasil), Pedro Flores-Crespo (UAQ, México) Rodrigo da Silva Pereira (UFBA, Brasil), Robert Verhine (UFBA - Brasil), Rosana Cruz (UFPI - Brasil), Rubens Barbosa Camargo (USP - Brasil), Sebastián Donoso Díaz (Universidad de Talca - Chile), Theresa Adrião (UNICAMP - Brasil), Vera Maria Vidal Peroni (UFRGS - Brasil).

Créditos e Agradecimentos:

Revisão de Língua Portuguesa, Abstract e Resumen: Programa de apoio às publicações científicas periódicas da UFPR

Arte e diagramação: Tiago Tavares (tiagotav@gmail.com)

Jornal de Políticas Educacionais

Universidade Federal do Paraná

Setor de Educação

Núcleo de Políticas Educacionais - NuPE/UFPR

Avenida Sete de Setembro, 2645

2 o andar, Sala 213

80.230-010 - Curitiba - PR - Brasil

Tel.: 41-3535-6264

jpe@ufpr.br

http://revistas.ufpr.br/jpe 